\title{
The 'new' wave of populist right-wing parties in Central and Eastern Europe: Explaining electoral support for the Conservative People's Party of Estonia
}

\author{
Siim Trumm (University of Nottingham)
}

Journal: Representation

Date of acceptance: 18/10/2018

\begin{abstract}
Rising support for populist right-wing parties has become a key story of recent decades. It has mainly been making headlines in Western democracies but is also becoming increasingly prevalent in Central and Eastern Europe. Despite there being strong evidence that campaigns influence electoral performance, and a large body of literature profiling the voters of populist right-wing parties, we still know little about the comparative relevance of parties' campaign efforts and voters' personal characteristics for supporting such parties. Merging data from the 2015 Estonian Candidate Study and the 2015 Estonian National Election Study, this article explains electoral support for the Conservative People's Party of Estonia. It finds that both individual-level and party-level factors influence voters' likelihood of casting their ballot for the populist right-wing party. Support for the party is higher in constituencies where it carries out more intense campaigns, and amongst voters who hold anti-establishment sentiments and are socially conservative. In contrast to populist right-wing parties in the West, however, antiimmigration feelings and Euroscepticism do not drive support for it. These findings show that support for populist right-wing parties is shaped by their campaign effort and their ability to tap into the 'right' kind of disillusionment.
\end{abstract}




\section{Introduction}

The growing popularity and electoral success of populist right-wing parties has been one of the key stories of recent decades. These parties are no longer marginalised and in the fringes of the society, but often leading the political discussion and credible options for casting one's ballot for. They are no longer seen as parties for "fruitcakes, loonies and closet racists" (BBC 2006), but as meaningful players in the political arena. Today, around fifty democracies have populist right-wing parties represented in their legislature, including such diverse countries like Austria, Brazil, Estonia, France, India, Germany, and Poland. It is essential to understand who votes for populist right-wing parties as they are playing an increasingly important role in shaping public discourse and legislative agenda.

The relevance of populist right-wing parties in the political arena has unsurprisingly led to a growing number of studies profiling their voters and examining the conditions under which such parties succeed. Yet, this literature has given little attention to the potential relevance of electoral campaigns. It is widely acknowledged in the study of voting behaviour that electoral campaigns influence what happens on the polling day (e.g., Fisher et al. 2016; Sudulich et al. 2013; Trumm 2016), particularly in the current political climate where party attachments are weak and the number of late deciders and floating voters is increasing (e.g., Dalton 2008, 2012; Lupo 2015; McAllister 2002). The potential relevance of campaign effects, however, has not transferred to the study of populist right-wing voting. It is important to utilise these insights and capture a broader range of factors when explaining support for the populist rightwing parties at the ballot box.

This study explores the recent electoral success of the Conservative People's Party of Estonia (EKRE). ${ }^{1}$ Who voted for EKRE at the 2015 parliamentary election? What is the comparative relevance of voters' individual-level characteristics and EKRE's campaign efforts in shaping whether someone casts her ballot for the party or not? I answer both questions using data from the 2015 Estonian Candidate Study and the 2015 Estonian National Election Study. The former allows me to capture the campaign effort put in place by EKRE candidates, and the latter allows me to capture voters' individual-level characteristics like their socio-economic situation, cultural attitudes, and demographic background. Taken together, this paper not only extends our understanding of electoral support for another increasingly prominent populist right-wing party in Central and Eastern Europe (CEE), but it also offers a first-cut evaluation of the comparative relevance of voters' personal characteristics and party-level campaign efforts in determining who casts her ballot for a populist right-wing party and who does not.

\footnotetext{
${ }^{1}$ The case study of EKRE is well-suited for extending our understanding of populist right-wing parties' success in CEE. First, Estonia arguably provides the toughest test for populist right-wing parties in the region. Not only was it the last CEE country with weak radical right-wing movements in 2015 (Minkenberg 2017), but it had also resisted such movements despite the presence of factors commonly linked to the success of extreme-right parties (Auers and Kasekamp 2009). Second, the party remains popular amongst the public, polling as high as $22 \%$ in July 2018 (Kanter Emor 2018). Whereas scholars have studied EKRE's public discourse (Kasekamp et al. 2018; Wierenga 2017), we still know very little about how this plays out with voters and what the key drivers for its electoral support are. Given that the next parliamentary election in Estonia will be held in March 2019, the latter is particularly important to understand. Finally, the availability of voter and candidate survey data from the 2015 election offers a rare opportunity to simultaneously assess the role of voters' individual-level characteristics and party-level campaign efforts in shaping populist right-wing vote.
} 
The analysis reveals that both individual-level and party-level factors influence whether someone casts her ballot for a populist right-wing party or not. As expected, EKRE draws its support disproportionately amongst voters who are socially conservative, mistrust politicians, and in precarious employment. EKRE is also more popular amongst men and voters who see Estonian as their primary identity. Individual-level factors, however, do not tell the full story. The findings also reveal that campaigns matter. Support for EKRE is higher in constituencies where its candidates put in place more intense campaign effort in the immediate run up to the polling day. Taken together, these findings emphasise that electoral support for populist rightwing parties is not given. It is concentrated amongst voters with a certain personal profile, but it is also influenced by voters' experiences during electoral campaigns.

This article is organised as follows. The next section surveys existing literature on voting for populist right-wing parties. I then provide some background information on EKRE, describe the data and methods, and present the empirical results. The paper finishes with a discussion of their implications.

\section{Who supports populist right-wing parties?}

The growing prominence of populist right-wing parties has unsurprisingly led to an increased academic interest in understanding what influences support for these parties. Research in this strand has generally focused on either individual-level data on voters' personal characteristics and vote choices or party-level data on populist right-wing parties' vote share over time and across constituencies. Although different in their approach, there are certain demand-side and supply-side factors that both highlight as shaping support for populist right-wing parties.

The demand-side factors, focusing on voters' personal profile and grievances, can be divided into three categories. First, economic grievances can motivate support for populist right-wing parties. According to this theory, perceived economic inequality and social deprivation fuel a sense of being 'left behind', resulting in resentment towards the political elite which, in turn, leads to the appeal of populist right-wing parties' anti-establishment message and blaming of an outgroup for one's economic struggles. As such, support for populist right-wing parties is expected to be higher amongst voters in insecure and low-paid employment, and those who are more pessimistic about the state of the economy (e.g., Arzheimer 2009; Cutts et al. 2011; Goodwin and Harris 2013). ${ }^{2}$ Second, support for populist right-wing parties can be seen as a cultural backlash against progressive change. The rise in liberal values, multiculturalism, and general openness of societies to outsiders has led to a sense of decline amongst some voters who resent the rising tide of progressive liberal values and the changing nature of societies, making them more receptive to the appeal of populist right-wing parties. As such, support for populist right-wing parties is seen to be higher amongst voters who are anti-immigration and Eurosceptic, socially conservative, and generally mistrustful towards the political elite (e.g., Allen 2017b; Ford et al. 2012; Oesch 2008; van Elsas 2017). Finally, demographic profile of

\footnotetext{
${ }^{2}$ Although the 'left behind' thesis is dominant, some scholars have found economic indicators to have either no effect or a negative effect on support for right-wing parties (Coffé et al. 2007; Lubbers and Scheepers 2002).
} 
voters has been shown to matter. The main characteristics that studies have highlighted here are gender, age, education, and national identity (e.g., Allen 2017a; Ford and Goodwin 2010; Rooduijn et al. 2017).

Existing studies of populist right-wing parties have also shown that there is some variation in the extent to which they tap into the different grievances in Eastern and Western Europe, and the nature of their discourse more broadly. On the one hand, populist right-wing parties in the two regions tend to frame different groups as the 'others'. Whereas immigrants take the role of scapegoats for resentment and are the core element in the political agenda for the populist right-wing parties in Western Europe, it is national minorities and neighbouring countries that are the main targets for such parties in Eastern Europe (e.g., Minkenberg 2013, 2017; Pytlas 2017). Immigration has simply not been, at least in the past, a salient social or political issue in the latter. Therefore, anti-immigration sentiments should provide a stronger cue for voting for populist right-wing parties in Western Europe, whereas being part of the majority versus minority group should play a more important role in Eastern Europe. On the other hand, the general discourse of populist right-wing parties in Eastern Europe tends to be more extreme and anti-democratic than that of their Western European counterparts. The political space that populist right-wing parties in Eastern Europe can operate in is more limited as mainstream parties in the region have traditionally been willing to adopt aspects of radical right ideology (e.g., Minkenberg 2002, 2013; Pytlas 2017). This suggests that voters of populist right-wing parties in Eastern European should be particularly dissatisfied with the existing political elite.

The supply-side factors, focusing on political opportunity structures and mobilising strategies of parties, emphasise the importance of how open a political system is to political newcomers in understanding where populist right-wing parties succeed (Arzheimer and Carter 2006). It is argued that the rise and success of populist right-wing parties is more likely in countries with proportional electoral systems (Norris 2005), media that is willing to give them a profile and cover issues that they want highlighted (Boomgarden and Vliegenthart 2007; Ellinas 2010), historical legacies that have given voters reasons to be sceptical of politicians (de Lange and Guerra 2009), and a political space they can operate in (Meguid 2005). Besides the political opportunity structures, the choices that populist right-wing parties make also matter. They benefit from building an effective party organisation (Art 2011; Carter 2005) and choosing a charismatic leader (Pauwels 2010). These factors, albeit important to understanding why support for populist right-wing parties varies across countries and elections, are not included in this study as they do not vary in the context of a single election.

Despite research on the voters of populist right-wing parties having become a minor industry, it still has limitations. On the one hand, this literature has predominantly focused on Western Europe. Although there is a growing body of studies that examine the nature of populist rightwing parties in Eastern Europe (e.g., Bustikova and Kitschelt 2009; Minkenberg 2013, 2017; Pytlas 2017), our understanding of which voters end up voting for populist right-wing parties 
is much more sporadic for Eastern Europe than it is for Western Europe. ${ }^{3}$ This is emphasised in the case of the Baltic States as no study to date, to the best of my knowledge, has examined the recent electoral success of EKRE. ${ }^{4}$ Whereas this does not of course mean that the patterns of support for populist right-wing parties are necessarily unique in Eastern Europe or Estonia, it is important to extend our understanding of who supports such parties in the region. On the other hand, literature on electoral support for populist right-wing parties fails to account what is widely recognised in voting behaviour literature; campaigns matter (e.g., Fisher et al. 2016; Sudulich et al. 2013; Trumm 2016). ${ }^{5}$ We live in an era where party loyalties are weakening, the number of late deciders and floating voters is rising, and issue voting is on the up (e.g., Dalton 2008, 2012; Lupo 2015; McAllister 2002). What happens in the immediate run up to the polling day is increasingly important in determining what party someone ultimately casts her ballot for. Yet, the campaign effects associated with voting for populist right-wing parties are largely overlooked. ${ }^{6}$ It is, therefore, important to build on existing literature and examine how important populist right-wing parties' campaign efforts are in influencing who votes for them, in absolute terms as well as relative to the importance of the different individual-level factors that have been shown to play a role.

This study addresses both limitations. It compares the importance of voters' individual-level characteristics and party-level campaign efforts in determining whether someone votes for a populist right-wing party or not, focusing on a CEE country as a case study.

\section{The emergence of EKRE}

EKRE is a relatively new party in Estonia's political landscape. It was established in March 2012 as a result of the merger between the Estonian Nationalist Movement and the People's Union of Estonia. This was effectively a marriage of a social movement and a political party. The newly-formed EKRE had several things going for it. The party did not have to start from scratch as it inherited the organisation and network of the People's Union of Estonia, it had a degree of automatic credibility as the People's Union of Estonia had served in government, it inherited Arnold Rüütel (former president of Estonia) as the honorary chairman from the People's Union of Estonia, and has had a charismatic and media-savvy leader in Mart Helme since its early days. ${ }^{7}$

\footnotetext{
${ }^{3}$ Recent studies by Allen (2017a), Bustikova (2014), de Lange and Guerra (2009), and Pirro (2014) are notable exceptions that do profile voters of populist right-wing parties in Eastern Europe.

${ }^{4}$ Existing studies of populist far-right in Estonia have focused on explaining the failure of this movement in the past (Auers and Kasekamp 2009), its nature and evolution (Auers and Kasekamp 2013, 2015), and the discourse and political stance of EKRE (Kasekamp et al. 2018; Wierenga 2017).

${ }^{5}$ The mechanisms through which campaigns influence voting are plentiful. They can raise voters' awareness of candidates and issues that are relevant to voting calculus (Jacobson 2013; Fridkin and Kenney 2011a). They can inform voters about candidates' qualifications, issue positions, etc., raise awareness of political conditions, and, crucially, prime voters to attach greatest electoral relevance to traits and issues where candidates believe to have an electoral advantage (Hillygus 2010). In addition, attacks on opposition can be memorable and influence the support for the target and the attacker (Lau et al. 2007), especially if they are focusing on topics that are relevant to governing and disseminated in an uncivil manner (Fridkin and Kenney 2011b).

${ }^{6}$ The notable exception is the study by Cutts and Goodwin (2014) that examines support for the British National Party at the 2010 British general election.

${ }^{7}$ For recent studies on EKRE, see Auers and Kasekamp (2015), Kasekamp et al. (2018), and Wierenga (2017).
} 
The political discourse that EKRE promotes is quite common to populist right-wing parties in CEE. It describes itself as a patriotic party whose main mission is to protect Estonian national values and interests (EKRE 2018). In a recent study of EKRE's media discourse, Kasekamp and others (2018) identified four key narratives in its political communication: an anti-Russia stance, Euroscepticism, promotion of family values, and anti-refugee sentiment. ${ }^{8}$ In terms of the party's communication style and image, EKRE opposes mainstream media and political correctness, and it tries to present itself as a new political force (Auers and Kasekamp 2015; Kasekamp et al. 2018). EKRE is an openly nationalist, socially-conservative party that uses cruder public discourse to engage with voters.

The electoral breakthrough of EKRE came at the 2015 parliamentary election and took many by surprise. Whereas party systems in CEE are remarkably unstable and volatile (Powell and Tucker 2014; Savage 2016), Estonian party system was quite consolidated by 2015, with the number parliamentary parties having decreased to just four after the 2011 election. Moreover, extreme right-wing movements had been electorally unsuccessful in the country for decades, despite the presence of factors often linked to their success (Auers and Kasekamp 2009), and EKRE itself only managed to gain $1.3 \%$ of the popular vote at the 2013 local elections. There was little to indicate that EKRE goes on to win $8.1 \%$ of the popular vote and seven seats (out of 101) at the 2015 parliamentary election. ${ }^{9}$

\section{Data and methods}

The analyses presented here rely on survey data from the 2015 Estonian Candidate Study and the voter study component of the 2015 Estonian National Election Study. These surveys are ideally suited for capturing the electoral choices and personal characteristics of voters as well as the campaign effort put in place by EKRE candidates. They were conducted close together, have an extensive reach in terms of the number of respondents, and ask voters and candidates about their actual electoral behaviour at the 2015 parliamentary election.

The voter study component of the 2015 Estonian National Election Study is used to capture voters' electoral choices and personal characteristics. The survey asked voters which party (if any) they cast their ballot for at the 2015 parliamentary election, about their socio-economic situation, cultural attitudes, demographic background, etc. It was carried out by Saar Poll, for the University of Tartu, in March 2015. It is ideal for capturing voters' electoral choices and personal characteristics, being the most far-reaching survey that has been recently conducted in Estonia in terms of the number of respondents and range of pertinent questions, and asking voters about their actual, not hypothetical, voting choices.

The 2015 Estonian Candidate Study is a post-election survey of candidates who stood at the 2015 parliamentary election, carried out in March and April 2015. The final sample includes 394 candidates ( $45.2 \%$ of all candidates) and is highly representative of the full population of

\footnotetext{
${ }^{8}$ EKRE is open to Russian-speakers becoming members, but only if they are Estonian nationalists who adhere to the party's constitution and see Estonia as a sovereign nation which they seek to protect Wierenga (2017).

${ }^{9}$ See Appendix A for information on EKRE's electoral performance by constituency and its electoral platform.
} 
candidates. When using the Duncan index of dissimilarity to compare the distribution of two key characteristics - partisanship and constituency - in the sample and the full population, it yields values of 0.06 and 0.07 , respectively. ${ }^{10}$ Moreover, the proportion of women in the full population and the sample is equal at $27 \%$, whereas the average age is similar (51 versus 50 years) and so is the proportion of successful candidates (8.4\% versus $11.6 \%)$. Data from the 2015 Estonian Candidate Study are used to capture the campaign effort of EKRE candidates and the extent to which they were embedded in the community they stood for election in. ${ }^{11}$

\section{Dependent variable}

The dependent variable in this study is EKRE vote. It is a straightforward indicator of whether a respondent cast her ballot for EKRE (coded 1) or not (coded 0$).{ }^{12}$ Recalled voting choice is a widely used indicator in voting behaviour literature to capture support for a particular party as it is, or at least could be, influenced by electoral campaigns (e.g., Allen 2017a; Rooduijn et al. 2017; Rydgren 2008). Therefore, it is well suited to simultaneously account for any effects associated with voters' individual-level characteristics as well as parties' electoral campaigns.

\section{Explanatory characteristics}

In line with the theoretical framework, four sets of explanatory characteristics are included in the study. First, measures of the cultural dimension are captured. Anti-immigration describes respondent's attitude towards a liberal immigration policy. It is operationalised as the extent to which a respondent agrees with the claim that 'obtaining Estonian citizenship should be made easier', ranging from 1 'completely agree' to 4 'completely disagree'. Euroscepticism captures respondent's attitude towards European integration. It is measured on a scale from 0 'integration should be pushed further' to 10 'integration has gone too far'. These indicators tap into the prevalence of the 'us versus them' attitude and how important voters believe that the protectionism of the status quo is. Moving on, social conservatism describes how liberal versus conservative the respondent is. It is operationalised as the extent to which she agrees with the statement that 'legalising same sex marriage was a right decision', ranging from 1 'completely agree' to 4 'completely disagree'. Finally, political mistrust captures how much the respondent trusts politicians as a group. It ranges from 0 'complete trust' 10 'no trust'. In line with existing evidence, I expect higher likelihood of voting for EKRE amongst voters who oppose a liberal immigration policy, are Eurosceptic, socially conservative, and mistrust politicians.

\footnotetext{
${ }^{10}$ See Appendix B for additional information on the survey sample, and Duncan and Duncan (1955) for further information on the Duncan index of dissimilarity.

${ }^{11}$ Candidate survey data have various advantages over official spending data and voter survey data for capturing campaign effects. On the one hand, campaign regulation in Estonia is unrestrictive (Erakondade Rahastamise Järelvalve Komisjon 2018). In addition to having no legally defined campaign period, parties are not required to declare their election spending on constituency-level, and the election spending reports filed by candidates only need to include expenditure funded with personal money. On the other hand, the voter survey that was carried out in 2015 did not ask respondents about party contact. As such, candidate survey data are preferred. It asked respondents about their overall campaign expenditure and whether they reside in the constituency they stood for election in, allowing for the creation of constituency-level indicators that tap into the campaign profile of EKRE candidates.

${ }^{12}$ Respondents who did not vote at the 2015 parliamentary election are not included in the analysis.
} 
Next, indicators of the economic dimension are included in the study. Economic pessimism captures how positively (or negatively) the respondent thinks of Estonia's economic situation. It is operationalised as her view on how Estonia's economy has performed in the last twelve months, ranging from 1 'got much better' to 4' got a lot worse'. Employment type describes the respondent's own employment situation. It distinguishes between respondents in full time employment (coded 1), in part time employment working 19-40 hours weekly (coded 2), in limited employment working 1-19 hours weekly (coded 3), receiving irregular income from working (coded 4), unemployed (coded 5), and receiving state benefits (coded 6). Given that support for populist right-wing parties is associated with economic insecurity, I expect voting for EKRE to be more likely amongst voters who display greater level of economic pessimism and who are in more precarious types of employment.

Third, the analysis controls for respondents' demographic profile. Age captures respondents' age at the time of the election. The age groups are as follows: 1 '18-24 years old', 2 '25-34 years old', 3 '35-44 years old', 4 '45-54 years old', 5 '55-64 years old', 6 '65-74 years old', and 7 ' $75+$ years old'. The existing evidence here is mixed. Whereas most studies of populist right-wing vote have found it to be higher amongst younger voters (Allen 2017a; Arzheimer 2011; van Elsas 2017), some have found the opposite (Ford et al. 2012; Inglehart and Norris 2016). I expect to find the latter in Estonia. Party attachment in Estonia is weak amongst the younger and older voters which makes them both open to switching to EKRE, but the profile of the party chairman Mart Helme as a former high-level diplomat in 1990s is more likely to be known amongst the latter. Gender is captured as a dichotomous variable, with males coded as 0 and females as 1. Education captures the respondent's highest level of qualification. It distinguishes between respondents who have finished primary education (coded 1), secondary education (coded 2), and higher education (coded 3). Identity captures whether the respondent considers herself to be Estonian (coded 1) or not (coded 0). ${ }^{13}$ I expect support for EKRE to be higher amongst men, older voters, the less well educated, and those who see Estonian as their primary identity.

Finally, two indicators of voters' campaign experience are included in the study. It is widely shown in voting behaviour literature that electoral support for parties and candidates is linked to their campaign effort, incumbency, and locality. Incumbency is not used here as all EKRE candidates were challengers. Campaign effort and locality of EKRE candidates, however, are included as they varied considerably across constituencies. Campaign effort captures the level of campaign intensity that EKRE candidates put forward in the run up to the polling day. It is operationalised as the average campaign expenditure of EKRE candidates in the respondent's constituency. Locality captures the embeddedness of EKRE candidates in the community that they stand for election. It is measured as the per cent of EKRE candidates in the respondent's constituency who live in that constituency, ranging from 0 'none' to 100 'all'. Both measures are obtained from the 2105 Estonian Candidate Study. In line with existing evidence, I expect both indicators to positively influence voters' likelihood of casting their ballot for EKRE.

\footnotetext{
${ }^{13}$ The vast majority of respondents $(86 \%)$ who do not consider themselves to be Estonian identify as Russians.
} 


\section{Empirical strategy}

The potential effects of the explanatory variables on voting for EKRE are evaluated using a logistic regression model with penalised maximum likelihood estimation. Logistic regression is used given the dichotomous nature of the dependent variable, whereas penalised maximum likelihood estimation is preferred given the rare occurrence of voting for EKRE. Although the party won $8.1 \%$ of the popular vote, it still constitutes a small minority and a rare event from the estimation point of view. Penalised maximum likelihood estimation, also known as Firth method, is the appropriate technique to model the occurrence of such events. ${ }^{14}$

\section{Explaining electoral support for EKRE}

The focus is now turned to exploring which explanatory factors have a systematic effect on voting for EKRE. Table 1 presents findings from the multivariate logistic regression.

It is evident that support for EKRE cannot be explained with any one or two characteristics. It is a function of a complex combination of factors, some related to voters' personal profile and beliefs but not all. First, focusing on the demographic indicators, two have a significant effect on voting for EKRE. The negative coefficient of -0.61 for gender reveals that women are less likely to vote for EKRE than men, whereas the positive coefficient of 3.50 for identity shows that those who see Estonian as their primary identity are significantly more likely to cast their ballot for EKRE than voters who do not. ${ }^{15}$ Both findings follow the theoretical expectations. I do not, however, find a significant effect associated with education or age. This suggests that electoral support for EKRE is not disproportionately higher amongst the older voters or those with lower educational qualifications. It is men and those whose primary identity is Estonian who are more inclined to vote for EKRE.

Second, the findings regarding the cultural and economic factors are intriguing. Note first that the decision to vote for EKRE does not appear to be driven by Euroscepticism or opposition to a liberal immigration policy, which are often considered key reasons for voting for populist right-wing parties. The effects associated with anti-immigration and Euroscepticism are in the expected direction, but neither reach the conventional level of statistical significance. ${ }^{16}$ There

\footnotetext{
${ }^{14}$ See, for example, Firth (1993) or Williams (2017) for additional information on using logistic regression with penalised maximum likelihood estimation when analysing rare events.

${ }^{15}$ The significant effect for identity primarily reveals a difference in EKRE support amongst voters who think of themselves as Estonian versus Russian, given that the vast majority (86\%) of respondents who do not identify as Estonians see themselves as Russians. This finding also suggests that anti-Russian rhetoric and nativism towards the Russian-speaking population, both key themes for the populist radical-right in Estonia (Auers and Kasekamp 2013; Kasekamp et al. 2018), has resonated with voters and become key for EKRE's electoral appeal. In a wider context, it is another example of national minorities, instead of immigrants, being assigned the role of 'others' in CEE (Minkenberg 2017).

${ }^{16}$ The non-significance of Euroscepticism and opposition to a liberal immigration policy are surprising as both are key themes in EKRE's political messages (Kasekamp et al. 2018). It is most likely explained by the fact that these themes, albeit important to EKRE's discourse, were not central to the voting calculus of many voters. On the one hand, Estonia is very positive about the European Union. Eurobarometer 82 was the last of such surveys conducted before the 2015 parliamentary election and shows Estonia as one of the most positive countries about the European Union, with only $7 \%$ of respondents having a negative image of it (European Commission 2014). The political opportunity for priming Euroscepticism as the key issue that voters should base their voting choice on was not there in spring 2015. On the other hand, the saliency of immigration was also low. Only 5\% of the
} 
is, however, evidence that negativity and dissatisfaction drives support for EKRE. In terms of negativity, the outgroup it is targeted against is simply not immigrants or the European Union but politicians. The positive coefficient of 0.16 shows that voters who are more mistrustful of politicians as a group are also more inclined to cast their ballot for EKRE. This is in line with the theoretical expectations and makes sense given the party's anti-establishment rhetoric and efforts to portray itself as a new political force (Auers and Kasekamp 2015). In addition, the extent to which someone holds socially liberal or conservative attitudes matters. The positive coefficient of 0.52 indicates that the more socially conservative the voter is, the more inclined she is to vote for EKRE. Again, given the party's emphasis on the promotion of family values and salient stance against the legalisation of same-sex marriage (Auers and Kasekamp 2015; Kasekamp et al. 2018), it is unsurprising that voters who are socially conservative have been able to identify EKRE as the party which their attitudes align with most. Finally, employment type matters to some degree. The positive coefficient of 1.48 means that those in very limited employment - i.e., working 1-19 hours weekly - are more likely to cast their ballot for EKRE than those who are in full time employment. There are no significant effects associated with other employment types or with economic pessimism. It is voters who are active in the labour market and in paid employment, but have very restricted working hours and limited earnings, who are particularly likely to vote for EKRE. These findings lend support to the idea that the cultural and economic dimensions are both relevant to understanding electoral support for the party.

Finally, the evidence further highlights the importance of focusing on voters' individual-level characteristics as well as party-level campaign dynamics when exploring electoral support for EKRE. I do not find evidence that the proportion of local candidates put forward by EKRE in the constituency impacts voter's likelihood of casting her ballot for the party, but the intensity of EKRE's constituency-level campaign effort is clearly relevant to understanding who votes for the party. The positive coefficient of 0.56 implies that the more intense campaigns EKRE candidates put in place in voter's constituency, the more likely she is to cast her ballot for the party. Campaign effort influences electoral support for the party even after controlling for all the individual-level characteristics. This implies that support for populist right-wing parties is not given, based on voters' personal profile and attitudes, but needs to be fought for. It is vital for parties like EKRE not only to identify their potential voters and have messages that would resonate with them, but also to undertake extensive campaign efforts so that voters have the knowledge and awareness to identify them as the parties of their choice.

\section{[TABLE 1 HERE]}

To provide further real-world meaning of the findings and compare the effect sizes associated with the independent variables, Table 2 presents the predicted values for voters' likelihood of casting their ballot for EKRE. For each effect, the particular characteristic varies as others are held constant at their mean.

respondents in Estonia mentioned it in Eurobarometer 82 as the most important problem (European Commission 2014). These themes were not electorally relevant enough to drive EKRE's electoral support in 2015. 
The comparison of effect sizes further highlights that support for EKRE is multifaceted. The strongest effect is associated with employment type as voters in limited employment are a lot more likely to vote for EKRE than voters in full time employment (28.4\% versus 9.7\%). The effects associated with the other factors are slightly smaller, but still highly relevant. In terms of the cultural dimension, voters who mistrust politicians are $11.5 \%$ more likely to vote for EKRE than those who trust politicians ( $15.5 \%$ versus $4.0 \%)$, and socially conservative voters are $9.3 \%$ more likely to cast their ballot for EKRE than those who are socially liberal (12.6\% versus $3.3 \%$ ). In terms of the demographic indicators, the effect associated with identity is of a similar size as those who identity as Estonians are 11.4\% more likely to vote for EKRE than those who do not (11.9\% versus $0.5 \%$ ), but gender carries a weaker effect with it as men are only $4.8 \%$ more likely to vote for EKRE than women (12.4\% versus $7.6 \%)$. These individuallevel characteristics are clearly relevant to understanding who votes for EKRE and who does not, but so is campaign effort. The minimum-to-maximum shift in campaign effort results in an effect on EKRE vote that is of a similar size to those associated with most individual-level characteristics. Voters are more likely to vote for EKRE when the intensity of its candidates' campaign effort in their constituency is higher. The likelihood of voting for EKRE increases by $9.7 \%$ when comparing voters in constituencies where EKRE candidates' average spend is $€ 0(6.7 \%)$ and $€ 2,000$ (16.4\%). It is evident that certain voters, in terms of their own personal characteristics, are more receptive to the party than others, but it is also the level of campaign effort put in place by its candidates that shapes its electoral fortunes.

\section{[TABLE 2 HERE]}

\section{Conclusions}

The popularity of populist right-wing parties has been one of the key success stories of recent times. Amid concerns about immigration and economic inequality, Euroscepticism, mistrust of politicians, and a sense of lost national identity amongst some, these parties have been able to win support in opinion polls and make electoral gains in many Western European and CEE countries. The parliamentary election of 2015 saw Estonia added to that list as EKRE gained seven seats in the Estonian parliament with $8.1 \%$ of the popular vote.

This study explores the relevance of different types of factors in understanding who votes for EKRE. Despite there being strong evidence that campaigns influence electoral outcomes and a large body of literature profiling populist right-wing voters, we still know very little about the comparative relevance of voters' personal characteristics and parties' campaign strategies for supporting parties like EKRE. Combining survey data from the 2015 Estonian Candidate Study and the 2015 Estonian National Election Study, this study pulls together insights from these two strands of literature. It finds that both individual-level and party-level factors shape voters' likelihood of voting for EKRE. Support for the party is higher in constituencies where its candidates undertake more intense campaigns, as well as amongst voters who are socially conservative, mistrust politicians, in limited employment, consider Estonian as their primary identity, and male. Interestingly, the effect associated with candidates' campaign effort is of a similar size to those associated with voters' individual-level characteristics. Taken together, it 
is apparent that electoral support for populist right-wing parties is multifaceted. It is linked to voters' personal profile, but also to the intensity of the campaign effort put in place by these parties in the immediate run up to the polling day.

There are three broader points arising from this study and its findings. First, the fact that both individual-level and party-level characteristics influence who votes for EKRE highlights the importance of giving more attention to what happens in the immediate run up to the polling day when explaining electoral support for populist right-wing parties. Literature on voting for populist right-wing parties, whether focusing on individual-level vote choice or constituencylevel vote share, has tended to explain this using either voters' individual-level characteristics like their demographic profile or contextual factors like issue ownership. Whereas both types of explanations are of course relevant and have been proven to matter, they fail to account for the potential importance of parties' electoral campaigns. It is widely acknowledged that party attachments are weakening amongst electorates and the number of late deciders is increasing. The evidence provided here lends further support to the idea that studies of electoral support for populist right-wing parties should extend their reach and simultaneously evaluate the role played in this by voters' individual-level characteristics and party-level campaign efforts.

Second, the findings indicate that populist right-wing parties need to be strategic about which resentment they should tap into to enhance their electoral appeal. EKRE's political discourse, as that of most parties, focused on multiple themes around the time of the 2015 parliamentary election (Kasekamp et al. 2018), but some were more influential than others in determining whether voters ultimately cast their ballot for an EKRE candidate or not. Whereas mistrust of the political establishment was a key driver of electoral support for EKRE, as was opposition to the adoption of socially liberal policies, Euroscepticism and anti-immigration feelings were not. This is not to say that the latter attitudes were not shared by supporters of EKRE, but that they were simply not as electorally relevant in the context of the 2015 parliamentary election as the previously mentioned resentments. The findings presented here suggest that electoral support for populist right-wing parties is influenced by their ability to tap into the 'right' kind of disillusionment when choosing their public discourse.

Finally, the findings further emphasise that there is considerable variation within the group of populist right-wing parties. In particular, they lend support to the idea that populist right-wing parties and their support base differ between Eastern and Western Europe (e.g., Allen 2017b; Minkenberg 2017; Pytlas 2017). Whereas immigrants tend to take on the role of scapegoats for resentment and be the primary target for populist right-wing parties and voters in Western Europe, ethnic minorities are seen to take on that role in Eastern Europe. The findings shown here support this thesis. Whereas anti-immigration sentiments were not key drivers for EKRE support at the 2015 parliamentary election, voters' self-perceived identity was important in understanding who voted for the party and who did not. Electoral support for the party was considerably higher amongst voters whose primary identity was Estonian than those who saw themselves as members of an ethnic minority first and foremost. This lends further support to the idea that the electorally relevant 'other' differs between Eastern and Western Europe. 


\section{Appendix A. EKRE and the 2015 parliamentary election}

EKRE's electoral campaign in the run up to the 2015 parliamentary election had an explicitly nationalistic undertone (EKRE 2014). For example, the party promised to fight against mass migration into Estonia, advocated direct democracy, called for the removal of signatures from the 2014 border treaty between Estonia and Russia, emphasised the need to enhance Estonia's defence capability, etc. Campaign messages such as these clearly resonated with a substantial minority of Estonian voters.

Table A1 presents the electoral results for EKRE at the 2015 parliamentary election, showing the number of valid votes cast for the party and its vote share in each constituency.

Table A1. Electoral support for EKRE by constituency

\begin{tabular}{lcc}
\hline Constituency & EKRE vote & EKRE vote share (\%) \\
\hline 1. Tallinn: Haabersti, Põhja-Tallinn, Kristiine & 2,986 & 5.3 \\
2. Tallinn: Kesklinn, Lasnamäe, Pirita & 3,396 & 4.6 \\
3. Tallinn: Mustamäe, Nõmme & 4,570 & 8.8 \\
4. Harjumaa (exc. Tallinn), Raplamaa & 7,050 & 8.0 \\
5. Hiiumaa, Läänemaa, Saaremaa & 3,770 & 11.2 \\
6. Lääne-Virumaa & 2,492 & 9.3 \\
7. Ida-Virumaa & 1,068 & 3.1 \\
8. Järvamaa, Viljandimaa & 3,054 & 7.9 \\
9. Jõgevamaa, Tartumaa (exc. Tartu) & 3,814 & 9.3 \\
10. Tartu & 3,109 & 6.9 \\
11. Võrumaa, Valgamaa, Põlvamaa & 4,275 & 9.6 \\
12. Pärnumaa & 7,188 & 18.2 \\
\hline Total & 46,772 & 8.1 \\
\hline
\end{tabular}




\section{Appendix B. The 2015 Estonian Candidate Study}

The 2015 Estonian Candidate Study includes 394 candidates who disclosed their partisanship and constituency they stood for election in. The detailed breakdown is presented in Table B1.

Table B1. The 2015 Estonian Candidate Study sample

\begin{tabular}{|c|c|c|}
\hline & Candidates $(\%)$ & Sample (\%) \\
\hline \multicolumn{3}{|l|}{ Partisanship } \\
\hline Conservative People's Party of Estonia & 14.3 & 15.0 \\
\hline Estonian Centre Party & 14.3 & 11.9 \\
\hline Estonian Greens & 4.6 & 5.1 \\
\hline Estonian Independence Party & 1.3 & 1.0 \\
\hline Estonian Reform Party & 14.2 & 14.5 \\
\hline Estonian United Left Party & 2.9 & 1.3 \\
\hline Free Party & 14.3 & 17.8 \\
\hline Party of People's Unity & 4.0 & 3.1 \\
\hline Social Democratic Party & 14.3 & 14.0 \\
\hline Union of Pro Patria and Res Publica & 14.3 & 15.3 \\
\hline \multirow[t]{2}{*}{ Independent } & 1.4 & 1.3 \\
\hline & \multicolumn{2}{|c|}{ Duncan index $=0.06$} \\
\hline \multicolumn{3}{|l|}{ Constituency } \\
\hline 1. Tallinn: Haabersti, Põhja-Tallinn, Kristiine & 9.3 & 11.2 \\
\hline 2. Tallinn: Kesklinn, Lasnamäe, Pirita & 11.6 & 9.1 \\
\hline 3. Tallinn: Mustamäe, Nõmme & 8.1 & 7.6 \\
\hline 4. Harjumaa (exc. Tallinn), Raplamaa & 13.2 & 12.2 \\
\hline 5. Hiiumaa, Läänemaa, Saaremaa & 6.2 & 8.9 \\
\hline 6. Lääne-Virumaa & 5.6 & 6.6 \\
\hline 7. Ida-Virumaa & 7.0 & 7.4 \\
\hline 8. Järvamaa, Viljandimaa & 7.0 & 7.6 \\
\hline 9. Jõgevamaa, Tartumaa (exc. Tartu) & 7.7 & 7.1 \\
\hline 10. Tartu & 8.0 & 6.9 \\
\hline 11. Võrumaa, Valgamaa, Põlvamaa & 8.7 & 8.9 \\
\hline \multirow[t]{2}{*}{ 12. Pärnumaa } & 7.6 & 6.6 \\
\hline & \multicolumn{2}{|c|}{ Duncan index $=0.07$} \\
\hline
\end{tabular}




\section{Bibliography}

Allen, T.J. 2017a. All in the Party Family? Comparing Far Right Voters in Western and PostCommunist Europe. Party Politics 23/3: 274-285.

Allen, T.J. 2017b. Exit to the Right? Comparing Far Right Voters and Abstainers in Western Europe. Electoral Studies 50: 103-115.

Arzheimer, K. 2009. Contextual Factors and the Extreme Right Vote in Western Europe, 1980-2002. American Journal of Political Science 53/2: 259-275.

Arzheimer, K. 2011. Electoral Sociology - Who Votes for the Extreme Right and Why - and When? In U.Backes and P.Moreau (eds.) The Extreme Right in Europe: Current Trends and Perspectives. Göttingen: Vandenhoeck \& Ruprecht, pp. 35-50.

Arzheimer, K. and Carter, E. 2009. How (Not) to Operationalize Subnational Political Opportunity Structures: A Critique of Kestilä and Söderlund's Study of Regional Elections. European Journal of Political Research 48/3: 335-358.

Art, D. 2011. Inside the Radical Right: The Development of Anti-Immigrant Parties in Western Europe. New York: Cambridge University Press.

Auers, D. and Kasekamp, A. 2009. Explaining the Electoral Failure of Extreme-Right Parties in Estonia and Latvia. Journal of Contemporary European Studies 17/2: 241-254.

Auers, D. and Kasekamp, A. 2013. Comparing Radical-Right Populism in Estonia and Latvia. In B.Mral, M.KhosraviNik, and R.Wodak, (eds.). Right-Wing Populism in Europe: Politics and Discourse. London: Bloomsbury Academic, pp. 235-248.

Auers, D. and Kasekamp, A. 2015. The Impact of Radical Right Parties in the Baltic States. In M.Minkenberg (ed.) Transforming the Transformation? The East European Radical Right in the Political Process. Abingdon: Routledge, pp. 137-153.

BBC. 2006. UKIP Demands Apology from Cameron. Available online at: news.bbc.co.uk/1/hi/4875026.stm [accessed 28 February 2018].

Boomgaarden, H.G. and Vliegenthart, R. 2007. Explaining the Rise of Anti-Immigrant Parties: The Role of News Media Content. Electoral Studies 26/2: 404-417.

Bustikova, K. and Kitschelt, H. 2009. The Radical Right in Post-Communist Europe: Comparative Perspectives on Legacies and Party Competition. Communist and PostCommunist Studies 42/4: 459-483.

Bustikova, K. 2014. Revenge of the Radical Right. Comparative Political Studies 47/12: 1738-1765.

Carter, E. 2005. The Extreme Right in Western Europe: Success or Failure? Manchester: Manchester University Press.

Coffé, H., Heyndels, B. and Vermeir, J. 2007. Fertile Grounds for Extreme Right-Wing Parties: Explaining the Vlaams Blok's Electoral Success. Electoral Studies 26/1: 142155.

Cutts, D. and Goodwin, M.J. 2014. Getting out the Right-Wing Extremist Vote: Extreme Right Party Support and Campaign Effects at a Recent British General Election. European Political Science Review 6/1: 93-114.

Cutts, D., Ford, R. and Goodwin, M. 2011. Anti-Immigrant, Politically Disaffected or Still Racist after All? Examining the Attitudinal Drivers of Extreme Right Support in Britain in the 2009 European Elections. European Journal of Political Research 50/3: 418-440. 
Dalton, R. 2008. Citizen Politics: Public Opinion and Political Parties in Advanced Industrial Democracies. Washington: Congressional Quarterly Press.

Dalton, R. 2012. The Apartisan American: Dealignment and Electoral Change. Washington: CQ Press.

de Lange, S.L. and Guerra, S. 2009. The League of Polish Families between East and West, Past and Present. Communist and Post-Communist Studies 42/4: 527-549.

Duncan, O.D. and Duncan, B. 1955. A Methodological Analysis of Segregation Indexes. American Sociological Review 20/2: 210-217.

EKRE. 2014. Riigikogu 2015. Available online at: www.ekre.ee/riigikogu-2015 [accessed 15 August 2018].

EKRE. 2018. Erakond. Available online at: www.ekre.eelerakond [accessed 15 August 2018].

Ellinas, A.A. 2010. The Media and the Far Right in Western Europe. New York: Cambridge University Press.

Erakondade Rahastamise Järelvalve Komisjon. 2018. Valimiskampaaniad. Available online at: www.erjk.eelet/aruanded/valimiskampaaniad [accessed 28 February 2018].

European Commission. 2014. Standard Eurobarometer 82. Available online at: http://ec.europa.eu/commfrontoffice/publicopinion/archives/eb/eb82/eb82_first_en.pdf [Accessed 13 August 2018].

Firth, D. 1993. Bias Reduction of Maximum Likelihood Estimates. Biometrika 80/1: 27-38.

Fisher, J., Fieldhouse, E., Johnston, R., Pattie, C. and Cutts, D. 2016. Is All Campaigning Equally Positive? The Impact of District Level Campaigning on Voter Turnout at the 2010 British General Election. Party Politics 22/2: 215-226.

Ford, R. and Goodwin, M.J. 2010. Angry White Men: Individual and Contextual Predictors of Support for the British National Party. Political Studies 58/1: 1-25.

Ford, R., Goodwin, M.J. and Cutts, D. 2012. Strategic Eurosceptics and Polite Xenophobes: Support for the United Kingdom Independent Party (UKIP) in the 2009 European Parliament Elections. European Journal of Political Research 51/2: 204-234.

Fridkin, K.L. and Kenney, P.J. 2011a. The Role of Candidate Traits in Campaigns. Journal of Politics 73/1: 61-73.

Fridkin, K.L. and Kenney, P.J. 2011b. Variability in Citizens' Reactions to Different Types of Negative Campaigns. American Journal of Political Science 55/2: 307-325.

Goodwin, M. and Harris, G. 2013. Rallying Intolerance in the Valleys: Explaining Support for the Extreme Right in Wales. British Politics 8/4: 433-456.

Hillygus, D.S. 2010. Campaign Effects on Vote Choice. In J.E.Leighley (ed.) The Oxford Handbook of American Elections and Political Behavior. Oxford: Oxford University Press, pp. 326-345.

Inglehart, R.F. and Norris, P. 2016. Trump, Brexit, and the Rise of Populism: Economic Have-Nots and Cultural Backclash. Available online at: research.hks.harvard.edu/publications/getFile.aspx?Id=1401 [accessed 28 February 2018].

Jacobson, G.C. 2013. The Politics of Congressional Elections. New York: Pearson.

Kantar Emor. 2018. Erakondade Toetusreitingud. Available online at: www.emor.eelerakondade-toetusreitingud [accessed 09 August 2018] 
Kasekamp, A., Madisson, M-L. and Wierenga, L. 2018. Discursive Opportunities for the Estonian Populist Radical Right in a Digital Society. Problems of Post-Communism OnlineFirst.

Lau, R.L., Sigelman, L. and Rovner, I.B. 2007. The Effects of Negative Political Campaigns: A Meta-Analytic Reassessment. Journal of Politics 69/4: 1176-1209.

Lubbers, M. and Scheepers, P. 2002. French Front National Voting: A Micro and Macro Perspective. Ethnic and Racial Studies 25/1: 120-149.

Lupo, N. 2015. Party Brands in Crisis: Partisanship, Brand Dilution, and the Breakdown of Political Parties in Latin America. Cambridge: Cambridge University Press.

McAllister, I. 2002. Calculating or Capricious? The New Politics of Late Deciding Voters. In D.M.Farrell and R.Schmitt-Beck (eds.) Do Political Campaigns Matter? Campaign Effects in Elections and Referendums. London: Routledge, pp. 22-40.

Meguid, B.M. 2005. Competition between Unequals: The Role of Mainstream Party Strategy in Niche Party Success. American Political Science Review 99/3: 347-359.

Minkenberg, M. 2002. The Radical Right in Postsocialist Central and Eastern Europe: Comparative Observations and Interpretations. Easter European Politics and Societies 16/2: 335-362.

Minkenberg, M. 2013. From Pariah to Policy-Maker? The Radical Right in Europe, West and East: Between Margin and Mainstream. Journal of Contemporary European Studies 21/1: 5-24.

Minkenberg, M. 2017. The Radical Right in Eastern Europe: Democracy under Siege. New York: Palgrave Pivot.

Norris, P. 2005. Radical Right: Voters and Parties in the Electoral Market. Cambridge: Cambridge University Press.

Oesch, D. 2008. Explaining Workers' Support for Right-Wing Populist Parties in Western Europe: Evidence from Austria, Belgium, France, Norway, and Switzerland. International Political Science Review 29/3: 349-373.

Pauwels, T. 2010. Explaining the Success of Neo-Liberal Populist Parties: The Case of Lijst Dedecker in Belgium. Political Studies 58: 1009-1029.

Pirro, A.L.P. 2014. Digging into the Breeding Ground: Insights into the Electoral Performance of Populist Radical Right Parties in Central and Eastern Europe. East European Politics 30/2: 246-270.

Powell, E.M. and Tucker, J.A. 2014. Revisiting Electoral Volatility in Post-Communist Countries: New Data, New Results and New Approaches. British Journal of Political Science 44/1: 123-147.

Pytlas, B. 2017. Radical Right Parties in Central and Eastern Europe: Mainstream Party Competition and Electoral Fortune. London: Routledge.

Rooduijn, M., Burgoon, B., van Elsas, E.J. and van de Werfhorst, H.G. 2017. Radical Distinction: Support for Radical Left and Radical Right Parties in Europe. European Union Politics 18/4: 536-559.

Rydgren, J. 2008. Immigration Sceptics, Xenophobes or Racists? Radical Right-Wing Voting in Six West European Countries. European Journal of Political Research 47/6: 737765. 
Savage, L. 2016. Party System Institutionalization and Government Formation in New Democracies. World Politics 68/3: 499-537.

Sudulich, L., Wall, M. and Farrell, D.M. 2013. Why Bother Campaigning? Campaign Effectiveness in the 2009 European Parliament Election. Electoral Studies 32/4: 768778.

Trumm, S. 2016. What Does It Take to Get Elected in a Post-Communist Democracy? Explaining the Success and Failure of Parliamentary Candidates in Estonia. East European Politics and Societies and Cultures 30/1: 169-188.

van Elsas, E.J. 2017. Appealing to the 'Losers'? The Electorates of Left-Wing and RightWing Eurosceptic Parties Compared, 1989-2014. Electoral Studies 50: 68-79.

Wierenga, L. 2017. Russians, Refugees and Europeans: What Shapes the Discourse of the Conservative People's Party of Estonia? Humanities and Social Sciences Latvia 25/1: 4-19.

Williams, R. 2017. Analyzing Rare Events with Logistic Regression. Available online at: www3.nd.edu/ rwilliam/stats3/rareevents.pdf [accessed 28 February 2018]. 
Table 1. Who votes for EKRE?

\begin{tabular}{|c|c|}
\hline & EKRE vote \\
\hline Age & $0.08(0.12)$ \\
\hline Gender & $-0.61 *(0.30)$ \\
\hline \multicolumn{2}{|l|}{ Education $^{\wedge}$} \\
\hline Secondary & $0.20(0.50)$ \\
\hline Higher & $0.88(0.54)$ \\
\hline Identity & $3.50 *(1.47)$ \\
\hline Anti-immigration & $0.24(0.17)$ \\
\hline Euroscepticism & $0.01(0.05)$ \\
\hline Social conservatism & $0.52 * *(0.19)$ \\
\hline Political mistrust & $0.16 *(0.08)$ \\
\hline Economic pessimism & $0.21(0.18)$ \\
\hline \multicolumn{2}{|l|}{ Employment type $\mathrm{e}^{\wedge \wedge}$} \\
\hline Part time employment (19-40h) & $0.84(0.60)$ \\
\hline Limited employment (1-19h) & $1.48 *(0.74)$ \\
\hline Irregular income & $0.50(0.66)$ \\
\hline Unemployed & $-0.40(0.75)$ \\
\hline Income from benefits & $-0.36(0.44)$ \\
\hline Campaign effort & $0.56 *(0.27)$ \\
\hline Locality & $-0.00(0.01)$ \\
\hline Constant & $-10.50 * *(1.91)$ \\
\hline Observations & 644 \\
\hline Penalised log likelihood & -132 \\
\hline
\end{tabular}


Table 2. Predicted likelihood of voting for EKRE

\begin{tabular}{lrc}
\hline & \multicolumn{2}{c}{ EKRE vote (\%) } \\
\hline Gender & Male & 12.4 \\
& Female & 7.6 \\
Identity & & \\
& Non-Estonian & 0.5 \\
Social conservatism & Estonian & 11.9 \\
& & \\
& Socially liberal & 3.3 \\
Political mistrust & Socially conservative & 12.6 \\
& & \\
& Complete trust & 4.0 \\
Indifferent & 8.1 \\
Employment type & Complete mistrust & 15.5 \\
\multicolumn{2}{c}{ Limited employment (1-19h) } \\
Campaign effort \\
No effort (€0 per candidate)
\end{tabular}

